\title{
A genome-wide scan for preeclampsia in the Netherlands
}

Augusta MA Lachmeijer*,1,2, Reynir Arngrímsson ${ }^{3}$, Esther J Bastiaans ${ }^{1}$, Michael L Frigge ${ }^{4}$, Gerald Pals ${ }^{1}$, Sigrun Sigurdardóttir ${ }^{4}$, Hreinn Stéfansson ${ }^{4}$, Birgir Pálsson ${ }^{4}$, Dan Nicolae ${ }^{4,5}$, Augustin Kong ${ }^{4,6}$, Jan G Aarnoudse ${ }^{7}$, Jeff R Gulcher ${ }^{4}$, Guustaaf A Dekker ${ }^{8}$, Leo P ten Kate ${ }^{1}$ and Kári Stéfansson*,4

${ }^{1}$ Department of Clinical Genetics and Human Genetics, Vrije Universiteit Medical Centre, Amsterdam, The Netherlands; ${ }^{2}$ Department of Obstetrics and Gynaecology, Vrije Universiteit Medical Centre, Amsterdam, The Netherlands; ${ }^{3}$ Medical Genetics Unit, Faculty of Medicine, University of Iceland, Reykjavik, Iceland; ${ }^{4}$ deCODE Genetics, Reykjavik, Iceland; ${ }^{5}$ Department of Statistics, University of Chicago, Chicago, USA; ${ }^{6}$ Department of Human Genetics, University of Chicago, Chicago, USA; ${ }^{7}$ Department of Obstetrics and Gynecology, Academic Hospital, Groningen, The Netherlands; ${ }^{8}$ Department of Obstetrics and Gynecology, North West Adelaide Health Service, University of Adelaide, South Australia

Preeclampsia, hallmarked by de novo hypertension and proteinuria in pregnancy, has a familial tendency. Recently, a large Icelandic genome-wide scan provided evidence for a maternal susceptibility locus for preeclampsia on chromosome 2 p13 which was confirmed by a genome scan from Australia and New Zealand (NZ). The current study reports on a genome-wide scan of Dutch affected sib-pair families. In total 67 Dutch affected sib-pair families, comprising at least two siblings with proteinuric preeclampsia, eclampsia or HELLPsyndrome, were typed for $\mathbf{2 9 3}$ polymorphic markers throughout the genome and linkage analysis was performed. The highest allele sharing lod score of 1.99 was seen on chromosome $12 q$ at $109.5 \mathrm{cM}$. Two peaks overlapped in the same regions between the Dutch and Icelandic genome-wide scan at chromosome $3 p$ and chromosome 15q. No overlap was seen on $2 \mathrm{p}$. Re-analysis in 38 families without HELLP-syndrome (preeclampsia families) and 34 families with at least one sibling with HELLP syndrome (HELLP families), revealed two peaks with suggestive evidence for linkage in the non-HELLP families on chromosome 10q (lod score 2.38, D10S1432, $93.9 \mathrm{cM}$ ) and 22q (lod score 2.41, D22S685, $32.4 \mathrm{cM}$ ). The peak on 12q appeared to be associated with HELLP syndrome; it increased to a lod score of 2.1 in the HELLP families and almost disappeared in the preeclampsia families. A nominal peak on chromosome 11 in the preeclampsia families showed overlap with the second highest peak in the Australian/NZ study. Results from our Dutch genomewide scan indicate that HELLP syndrome might have a different genetic background than preeclampsia. European Journal of Human Genetics (2001) 9, 758-764.

Keywords: preeclampsia; genetics; linkage; genome-wide scan; polymorphic markers; sib-pair

\footnotetext{
*Correspondence: AMA Lachmeijer, MD, Vrije Universiteit Medical Centre, Faculty of Medicine, Department of Clinical Genetics and Human Genetics, Van der Boechorststraat 7, 1081 BT, Amsterdam, The Netherlands. Tel: +31 20 4448270; Fax: +31 20 4448285;

E-mail: ama.lachmeijer.humgen@med.vu.nl

or K Stéfansson, MD PhD, DeCODE Genetics, Lynghals 1, 101 Reykjavík, Iceland. Tel: +354 5771900; Fax: +354 5771901;

E-mail: kstefans@decode.is

Received 4 October 2000; revised 3 July 2001; accepted 3 July 2001
}

\section{Introduction}

Preeclampsia is still a leading cause of pregnancy-related maternal and foetal morbidity and mortality in developed countries. ${ }^{1}$ A strong familial factor in the aetiology of preeclampsia has been established ${ }^{2-4}$ and to assess the underlying mode of inheritance, systematic family studies have been done. Proposed inheritance models range from a 
maternal single recessive gene model, ${ }^{2,3,5}$ to models involving influence of the foetal genotype, ${ }^{6,7}$ homozygosity for a single recessive gene shared by mother and foetus, ${ }^{8}$ and models involving a dominant maternal gene with reduced penetrance. ${ }^{3}$ Summarising all systematic family studies, Arngrimsson et al concluded that a major dominant gene model with reduced penetrance, possibly depending on foetal genotype, or multi factorial inheritance, fitted the available data best. ${ }^{9}$

Finding susceptibility genes for preeclampsia has proved difficult. Several candidate gene studies have not provided consistent evidence for association between putative susceptibility genes and preeclampsia. ${ }^{10-19}$

Four genome-wide linkage studies have been performed so far. Hayward et al published the first genome-wide linkage study, designing an exclusion map for preeclampsia. $^{20}$ In the second genome scan Harrison et al ${ }^{21}$ suggested the presence of a candidate region on chromosome $4 \mathrm{q}$. The outcome of both these rather small studies were not in agreement with each other, nor did they confirm any of the previously published associations with candidate genes. Recently, Arngrímsson et $a^{22}$ published a genome-wide scan comprising a large number of affected women $(n=343)$ from 124 pedigrees. Using 440 polymorphic micro satellite markers and parametric (modeldependent) as well as non-parametric (model-independent) linkage analyses, a maternal susceptibility locus for preeclampsia was revealed on chromosome 2 p13 at $94.05 \mathrm{cM}$ which met the criteria for genome-wide

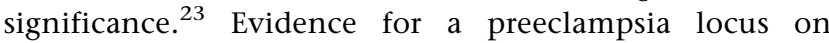
chromosome 2 was confirmed by a similar genome-wide scan in 34 families from Australia and New Zealand from Moses et al who found suggestive evidence of linkage to chromosome $2 \mathrm{q}$ at $144.7 \mathrm{cM}^{24}$ The current Dutch genome-wide scan was performed at the same laboratory as and in close collaboration with Arngrímsson and coworkers; 265 individuals from 67 Dutch families were genotyped at 293 microsatellite markers.

\section{Materials and methods}

Disease criteria

Affected women were recruited having suffered either from preeclampsia, HELLP syndrome or eclampsia during her first pregnancy ('strict' criteria), or from pregnancy induced hypertension only ('mild criteria') (Table 1 ).

\section{Recruitment of the Dutch affected sib-pair families with preeclampsia}

Between June 1995 and October 1997, 150 affected sib-pair families were recruited. Selection of 2940 women with a medical history of hypertension in pregnancy was through the medical records of the Vrije Universiteit Medical Centre in Amsterdam and the Academic Hospital in Groningen, The Netherlands, obstetrical databases of 20 other hospitals in the Netherlands and advertisements for the study. Medical family history questionnaires were sent out to all 2940 affected women. Medical records were examined for all women who responded; they had at least one affected sister $(n=178)$. Their affected sibling's medical records were examined similarly. Finally 150 families fulfilled the study criteria and were included. All families contained 332 affected women of whom 233 met the strict criteria, and 241 unaffected relatives. For the current genome scan 67 families were selected with siblings only affected by the strict criteria. These 67 families contained 58 families with two affected siblings, nine families with three affected siblings and 122 unaffected relatives.

\section{Genotyping}

DNA was extracted in the Netherlands from the peripheral blood of all individuals in the 67 families. Facilities for genotyping were made available by deCODE Genetics in Reykjavík, Iceland. Genotyping was done using 293 fluorescently labelled primers randomly distributed throughout the genome with an average spacing of $11.8 \mathrm{cM}$. The markers typed came from the CALC./Weber Human Screening Set Version 8 from Research Genetics. Average heterozygosity of markers in this set is reported to be $76-78 \%$ in CEPH families. PCR's, genotyping and editing of the genotypes were similar to the Icelandic scan. ${ }^{22}$ Marker orders and genetic distances used were obtained from publicly available genetic maps at the Marshfield Medical Clinic web site (www.marshmed.org). ${ }^{25}$

\section{Statistical analyses}

Data of the genome-wide scan were analysed using affectedonly non-parametric/allele sharing methods. ${ }^{26-28}$ Individ-

Table 1 Diagnostic criteria

\begin{tabular}{|c|c|c|}
\hline Criteria & Diagnosis & Definition \\
\hline \multirow[t]{3}{*}{ Strict } & Preeclampsia & $\begin{array}{l}\text { De novo hypertension (diastolic } \mathrm{BP}^{\mathrm{a}} \geqslant 90 \mathrm{mmHg} \text { with increment } \geqslant 20 \mathrm{mmHg} \text { from first trimester } \\
\text { diastolic } \mathrm{BP}^{\mathrm{b}} \text { ) and proteinuria } \geqslant 300 \mathrm{mg} / 24 \mathrm{~h} \text { or at least twice } 1+\text { on dipstick }\end{array}$ \\
\hline & Eclampsia & Seizures in a hypertensive pregnancy, with or without proteinuria \\
\hline & HELLP-syndrome & $\mathrm{LDH}^{\mathrm{c}} \geqslant 600 \mathrm{IU} / \mathrm{I}$ and $\mathrm{ASAT}^{\mathrm{d}}$ and $\mathrm{ALAT}^{\mathrm{e}}$ at least $70 \mathrm{IU} / \mathrm{I}$ and $\leqslant 100$ platelets $\times 10^{9} / \mathrm{I}$ \\
\hline Mild & $\mathrm{PIH}^{\mathrm{f}}$ & De novo hypertension in pregnancy without proteinuria \\
\hline
\end{tabular}

${ }^{a} B P=$ blood pressure; ${ }^{b}$ BP levels observed on at least two occasions, more than $6 \mathrm{~h}$ apart; ${ }^{\mathrm{C}}$ Lactic dehydrogenase; ${ }^{\mathrm{d}}$ Aspartate amino transferase; eAlanine amino transferase; ${ }^{\mathrm{f}} \mathrm{PIH}=$ pregnancy induced hypertension. 
uals, including males, not known to be affected or individuals only affected according to the mild criteria, were classified as 'unknown'. Mendelian inheritance was verified by using the LINKAGE package's 'unknown' program. ${ }^{26}$ All linkage results reported were produced by the ALLEGRO program $^{29}$ utilising the non-parametric method of linkage analysis. $^{28}$ Non-parametric linkage analysis assesses the amount of excess identity-by-descent (IBD) sharing among related affected as measured by a chosen scoring function. The scoring function used for this study was $S_{\text {all }}$, which is found to be quite powerful for a wide range of inheritance models. ${ }^{28,30}$ All calculations were fully multipoint, ie all markers from the same chromosome were used simulta- neously. The allele sharing lod scores reported here were, similar to the Icelandic scan, ${ }^{22}$ all computed with respect to the exponential model. ${ }^{27}$ Criteria for significance were based on guidelines published by Lander and Kruglyak; ${ }^{23}$ a lod score $>3.6$ ( $P$ value $<0.00002)$ indicates genome-wide significance, a lod score between 2.2 and $3.6(P<0.0007)$ indicates suggestive linkage and lod scores between 0.6 $(P<0.05)$ and $2.2(P<0.01)$ are nominal.

We re-analysed our data for families with only preeclampsia cases (preeclampsia families; $n=38$ ) and families with at least one sibling with HELLP-syndrome (HELLP families; $n=34)$ separately, since in the previous scans ${ }^{22,24}$ no HELLPsyndrome cases had been recruited.
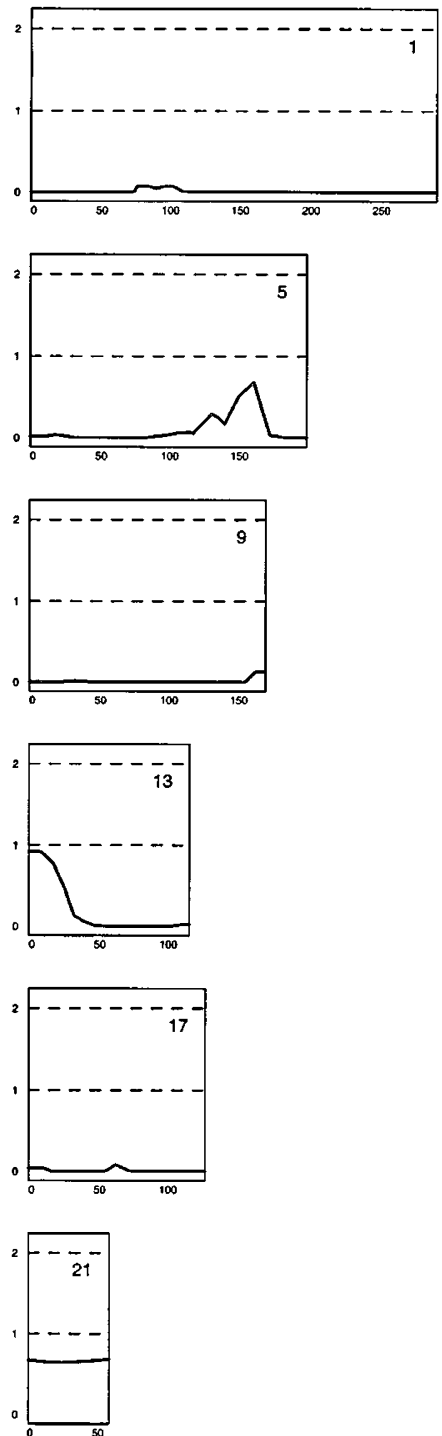
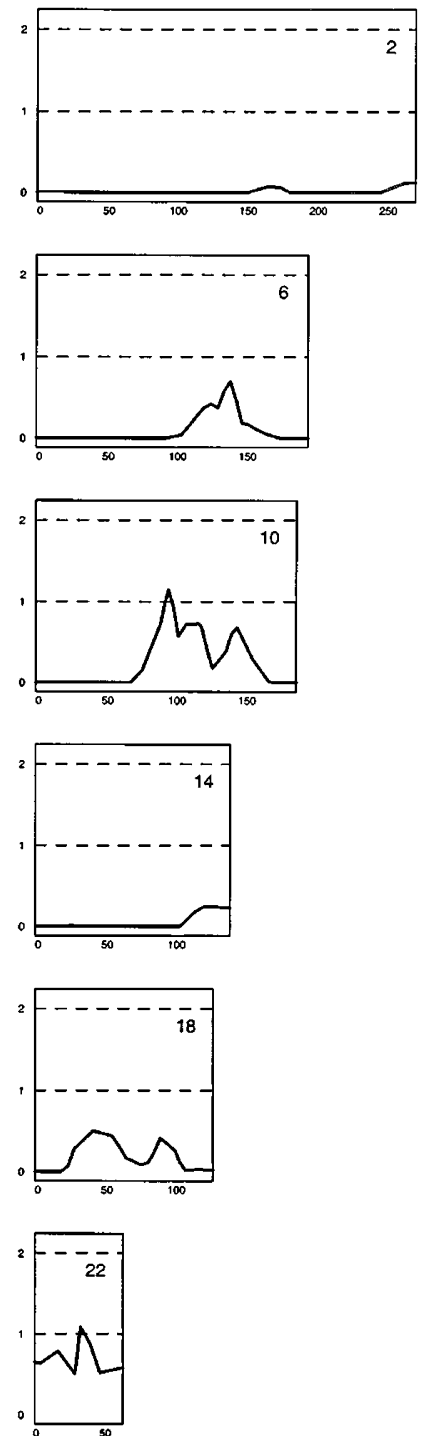
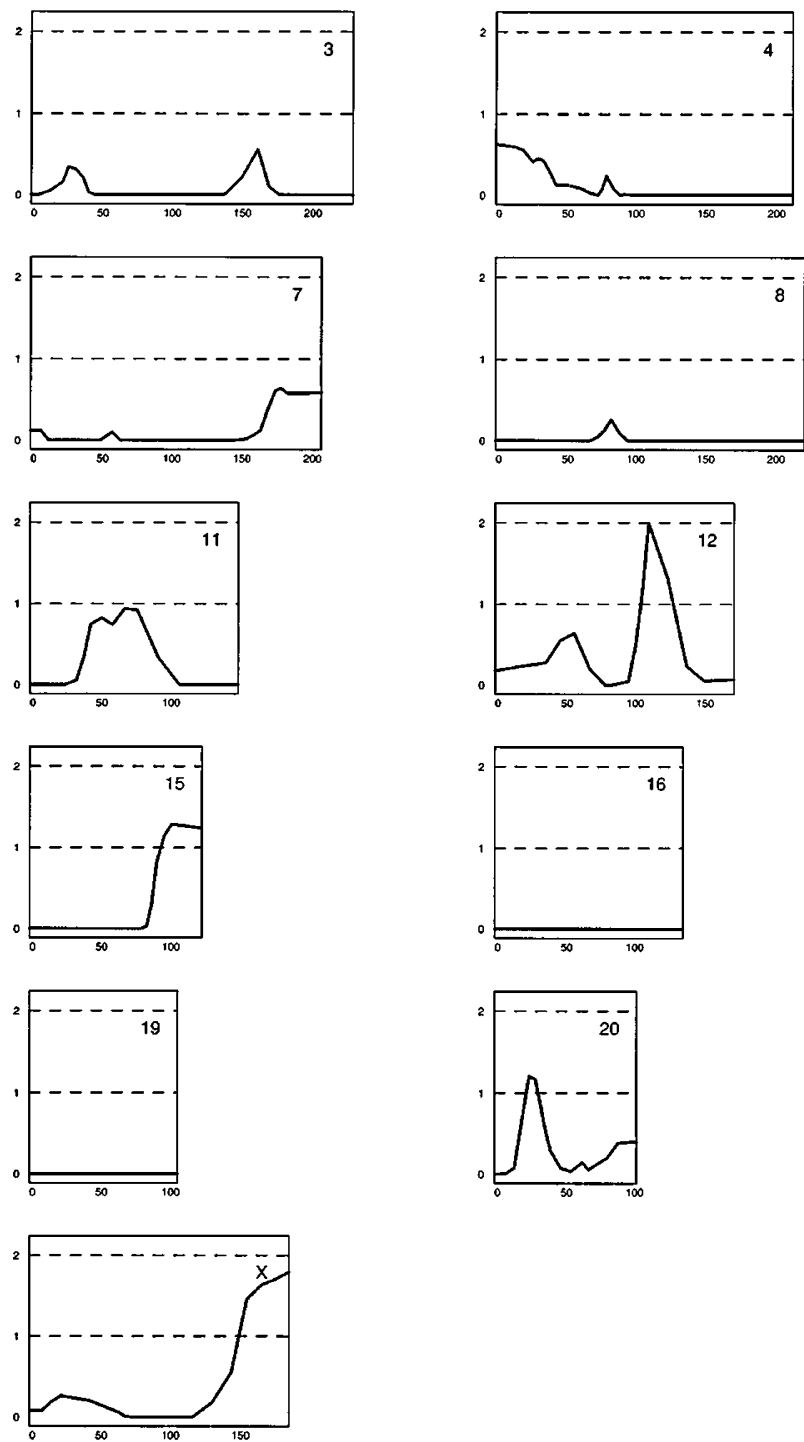

Figure 1 Results genome-wide scan in 67 Dutch families. Genome-wide scan for preeclampsia including HELLP-syndrome cases in 67 Dutch families, using a framework map of 293 polymorphic micro satellite markers. Each box represents a chromosome. The $y$-axis depicts the non-parametric multipoint lod score. The $x$-axis represents the $\mathrm{cM}$ distance of the markers used. 


\section{Results}

Results are shown in Figure 1. According to the criteria of Lander and Kruglyak ${ }^{23} 12$ regions showed nominal lod score peaks. Six of these peaks with lod scores between 1.0 and 2.2 were seen on respectively chromosome $10 \mathrm{q}$ at $93.9 \mathrm{cM}$ (D10S1432), $12 \mathrm{q}$ at $109.5 \mathrm{cM}(\mathrm{PAH}), 15 \mathrm{q}$ at $100.6 \mathrm{cM}$ (D15S816), 20p at $24.7 \mathrm{cM}$ (D20S851), 22q at $32.4 \mathrm{cM}$ (D22S685) and Xq at 165.1 cM (DXS9908). The highest lod score was $1.99(P=0.0012)$ on chromosome $12 \mathrm{q}(\mathrm{PAH})$ at $109.5 \mathrm{cM}$.

Because our strict disease criteria included HELLP-syndrome patients, in contrast to the Icelandic ${ }^{22}$ and Australian/ $\mathrm{NZ}^{24}$ scan, our data was re-analysed for families with (HELLP families) and without HELLP-syndrome (preeclampsia families). Analysis in the preeclampsia families showed two areas with suggestive evidence for linkage, despite the smaller sample size (38 families; 37 with two affected, one with three affected and 72 relatives) (Figure 2). The highest lod score of $2.41(P=0.00057)$ was seen on chromosome $22 \mathrm{q}$ at $32.4 \mathrm{cM}$ (D22S685), the second highest peak of $2.38(P=0.00057)$ was located on chromosome 10q at $93.9 \mathrm{cM}$ (D10S1432). The two highest nominal peaks were seen on chromosome 11 (lod score 1.84, $P=0.0015$; D11S2371, $76.1 \mathrm{cM}$ ) and chromosome 18 (lod score 1.65, $P=0.0027 ; \mathrm{D} 18 \mathrm{~S} 843,28.1 \mathrm{cM}$ ). In the analysis of the HELLP families (34 families; 10 with at least two HELLP-syndrome siblings, 24 with one HELLP-syndrome
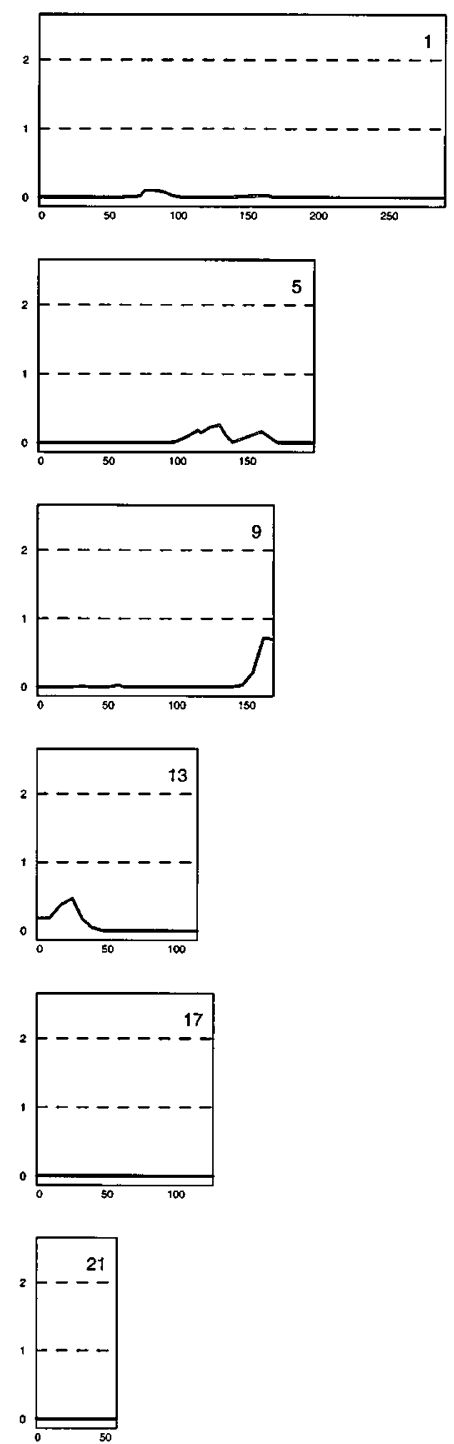
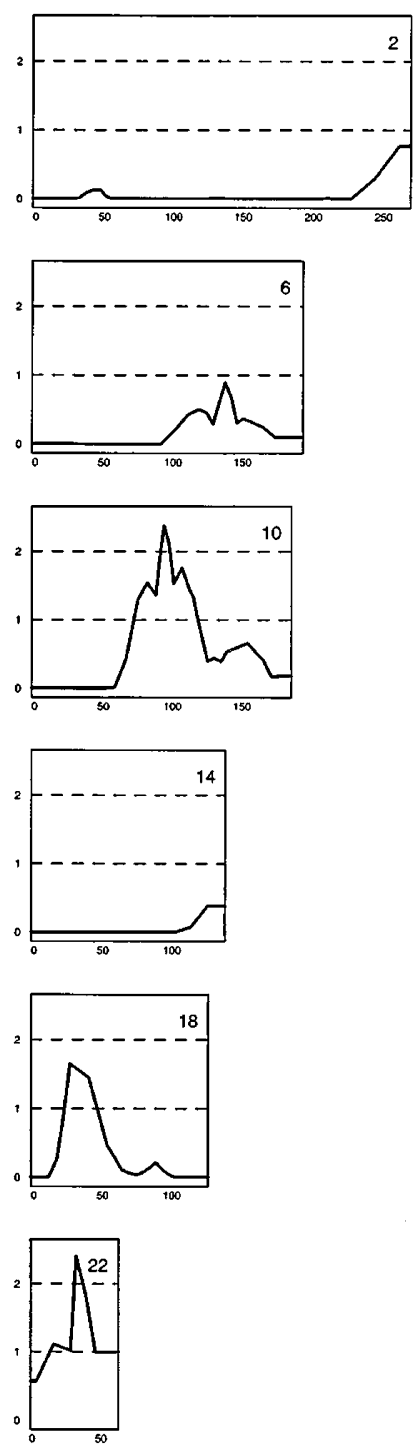
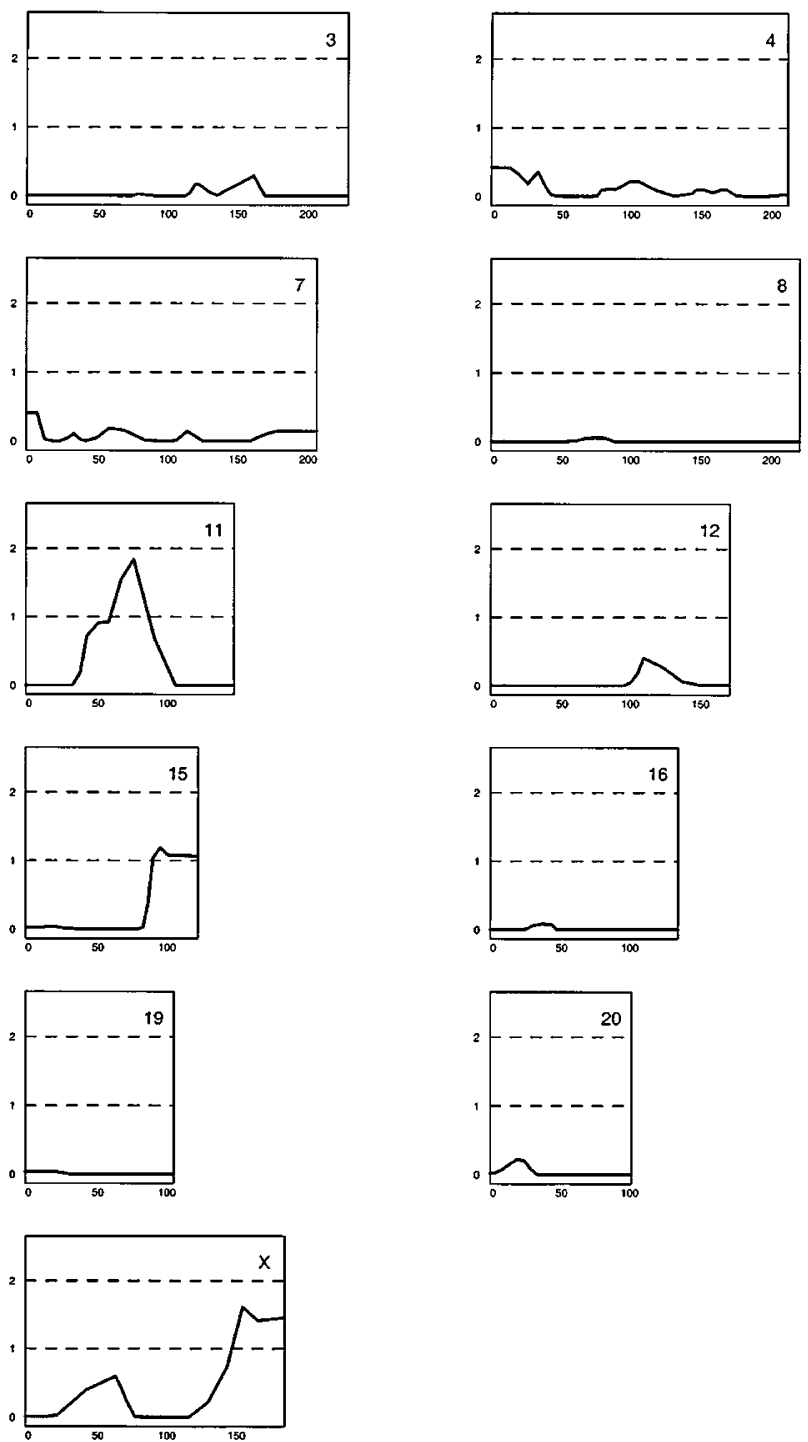

Figure 2 Results genome-wide scan in 38 Dutch families without HELLP-syndrome cases (preeclampsia families). Genome-wide scan for preeclampsia in 38 Dutch families, using a framework map of 293 polymorphic micro satellite markers. Each box represents a chromosome. The $\mathrm{y}$-axis depicts the non-parametric multipoint lod score. The $\mathrm{x}$-axis represents the cM distance of the markers used. 
sibling and at least one preeclamptic sibling and 65 relatives), these peaks were absent (data not shown). The peak on 12q, however, increased to a lod score of 2.1. The peak on Xq appeared to be additive in the preeclampsia and HELLP families analyses.

In none of the Dutch analyses relevant peaks were seen at previously published candidate loci, like angiotensinogen (1q42-43), endothelial nitric oxide synthase (7q36), methylenetetrahydrofolate reductase (1p36.3), TNF- $\alpha(6 \mathrm{p} 21)$ or chromosome $4 \mathrm{q} .{ }^{10,12,14,18,21}$

\section{Discussion}

Preeclampsia remains a puzzling disorder and this study reconfirms its complex genetic background. Although much effort was put into the recruitment of sib-pairs classifying to very stringent disease criteria, only nominal peaks came up in our initial analysis. The highest peak was found on chromosome $12 \mathrm{q}$ with a lod score of 1.99 . Interestingly, omission of the HELLP-syndrome cases from the analyses resulted in two peaks with evidence for suggestive linkage on chromosome $10 \mathrm{q}$ and $22 \mathrm{q}$, whereas the peak on chromosome $12 \mathrm{q}$ diminished considerably. In contrast, the chromosome 10 and 22 peaks were absent in the HELLP families, whereas the peak on $12 \mathrm{q}$ increased to 2.1. This may indicate that HELLP syndrome is a separate genetic entity, in contrast to the latest full consensus statement of the Australasian Society of the Study of Hypertension in Pregnancy, ${ }^{31}$ which states that HELLP-syndrome is a severe form of preeclampsia and therefore an even stronger strict disease criterium for the 'preeclampsia-phenotype' than preeclampsia alone. The only peak that appeared to contain contributions from both preeclampsia and HELLP families, was on Xq.

When we compare the results of our Dutch genome scan with the four genome-wide scans on preeclampsia published so $\operatorname{far}^{20-22,24}$ the following picture emerges. The first genome-wide exclusion map was published in 1992 by Hayward et al. ${ }^{20}$ Linkage analysis was based on a simple single recessive gene model using a limited number of families and only 43 markers which makes comparison with our current data difficult. In the second genome-wide scan from Australia ${ }^{21}$ parametric (recessive and dominant models) as well as non-parametric analyses revealed an interesting candidate region on chromosome $4 \mathrm{q}$ (lod score $=2.9$ ). Results of our initial scan and the subsequent analyses with and without HELLP-syndrome cases did not replicate this finding. Neither could we confirm the significant chromosome 2p13 peak found in the recent large Icelandic genome-wide scan. ${ }^{22}$

Since our Dutch genome-wide scan was set up similar to and performed in collaboration with the Icelandic group, close comparison between both scans was feasible and rendered two interesting overlapping regions on chromosome 3p (Dutch lod score 0.34, Icelandic lod score 1.02; D3S4545) and another on chromosome 15q (Dutch lod score 1.14, Icelandic lod score 0.95; D15S652-D15S816). The
Icelandic lod scores were those for the strict criteria. Removing HELLP-cases from our analyses reduced the overlap on chromosome $3 p$ but did not change the shared region on 15q. Other regions where both scans had nominal peaks were $2 \mathrm{q}, 13 \mathrm{p}$ and $18 \mathrm{p}$. The most recent large genome-wide scan using Australian and New Zealand (NZ) families ${ }^{24}$ had its highest peak on chromosome $2 \mathrm{q}$ (lod score $=2.58$ at $144.7 \mathrm{cM}$ ) with a broad basis overlapping the broad basis of the significant peak in the Icelandic scan on chromosome $2 p$ (lod score 4.77 at $94.05 \mathrm{cM}$ ). The area harbouring the two peaks was designated the 'PREG1' locus. Since the distance between the maximum lod score peaks was still quite large $(51 \mathrm{cM})$ it is possible that both scans revealed two separate loci instead of one. We did not see any overlapping peaks on chromosome 2 in our scan. After re-analysis without the HELLP-cases a new peak was revealed on chromosome 11 (lod score $1.84,76.1 \mathrm{cM})$. The Australian/NZ scan had its second highest peak on the same chromosome (lod score 2.02, $121.3 \mathrm{cM})$. As with the PREG1 locus, given the limited precision of estimates of the map location of disease genes contributing to complex traits as preeclampsia, these two peaks might suggest the presence of a second preeclampsia risk locus. Their mutual distance $(45 \mathrm{cM})$ might, however, also indicate two loci instead of one.

The two peaks with suggestive lod scores in our data were not found in the Icelandic ${ }^{22}$ and Australia/NZ ${ }^{24}$ scans. Their importance therefore remains to be elucidated.

Apart from the obvious population differences, several other factors may have influenced differences in outcome between our study and the Icelandic ${ }^{22}$ and Australian/ $\mathrm{NZ}^{24}$ scan. Both previous scans were performed in larger pedigrees using more markers $(n=400)$ than the Dutch $(n=293)$. Nonetheless, our 67 Dutch families contained 143 strictlydefined affected women compared to 186 strictly affected women in the 124 Icelandic pedigrees and 87 in the Australian/NZ scan. It is possible that expanding our Dutch scan to all 150 Dutch families with in total 332 affected including 233 strictly affected women, and using more markers, might reveal more similarities between the scans.

Furthermore, it is likely that preeclampsia is a genetically heterogeneous disorder which doesn't fit into simple recessive or dominant inheritance models. Numerous susceptibility genes with their individual mode of inheritance and penetrance may be involved, which emphasises the importance of using non-parametric linkage analyses in genome scans. Preeclampsia's heterogeneity is illustrated by the fact that the impressive significant peak on chromosome 2 p13 in the Icelandic scan ${ }^{22}$ came largely from two big families. These two families contained 17 affected of the total 343 affected in all Icelandic families; three of the total 157 mildly affected (2\%) and 14 of the total 186 strictly affected (7.5\%). This important locus might therefore be involved in only a part of the familial preeclampsia cases. Overlapping peaks like those on chromosome $3 p$ and $15 q$ with the Icelandic and on chromosome 11 with the Australian/ $\mathrm{NZ}^{24}$ 
scan may indicate loci that add to the overall risk profile of preeclampsia in a considerable number of patients worldwide.

Complicating the elucidation of genetic factors involved in preeclampsia further, there is substantial evidence that the foetal genotype plays a role in susceptibility for preeclampsia. ${ }^{7,32-39}$ The foetal genotype is likely to affect penetrance of maternal susceptibility genes. Our study focused on maternal susceptibility genes using the affected-only approach by analysing maternal DNA from affected sib-pairs, thereby minimising effects of the foetal genotype on penetrance. Nevertheless, although the 'preeclampsia-phenotype' was fully penetrant in these sib-pairs, this phenotype still might originate from different combinations and numbers of maternal susceptibility genes. When this is a true phenomenon, it will have substantially reduced the power of all five genome scans so far.

Adding to the reduction of power to find maternal susceptibility genes, in support of the Barker hypothesis ${ }^{40}$ there is evidence that non-genetic environmental factors are involved in the pathogenesis of preeclampsia; being born small or premature of a woman seems to increase her risk of developing preeclampsia in later life. ${ }^{41}$

In view of the complexity of the preeclampsia-trait, finding relatively little overlap between the five genome scans is maybe not particularly surprising. It is a fairly typical finding for genome-wide scans of complex traits performed in relatively small sample sizes. Merging raw data of published scans on a web-site and joining forces between groups studying the genetic background of preeclampsia might therefore greatly enhance the power of linkage studies to find maternal susceptibility genes in the future.

Finding maternal susceptibility genes that increase a woman's risk of preeclampsia would greatly enhance the possibilities for predicting risk pregnancies. The DutchIcelandic and Dutch-Australian/NZ overlapping areas may harbour such maternal risk loci. Our study suggests that these risk loci may be different for HELLP-syndrome than for preeclampsia.

\section{Acknowledgements}

This study was financially supported by The Netherlands Organisation for Scientific Research (NWO; Grant no. 950-10-612), Health Research and Development Council (Grant no. 28-2593), Wellcome Trust, UK, Icelandic Research Council, University of Iceland Research Fund, and deCODE Genetics Inc. We wish to thank professor R.T. Geirsson MD PhD, Department of Obstetrics and Gynaecology of the University Hospital in Reykjavik, Iceland for his kind support and advice throughout the study and preparation of the manuscript. We also wish to thank Barry Pieters, Guido van de Berk, Soe Janssens and Bibi de Leeuw for their enthusiastic help in collecting family data and drawing blood from participants, and all gynaecologists of the 21 Dutch Hospitals that were willing to facilitate our recruitment of families. Finally, we gratefully acknowledge all families for their participation in this study.

\section{References}

1 Ness RB, Roberts JM: Heterogeneous causes constituting the single syndrome of preeclampsia: a hypothesis and its implications. Am J Obstet Gynecol 1996; 175: $1365-1370$.

2 Chesley LC, Cooper DW: Genetics of hypertension in pregnancy: possible single gene control of pre-eclampsia and eclampsia in the descendants of eclamptic women. Br J Obstet Gynaecol 1986; 93: 898-908.

3 Arngrimsson R, Bjornsson S, Geirsson RT, Bjornsson H, Walker JJ, Snaedal G: Genetic and familial predisposition to eclampsia and pre- eclampsia in a defined population. Br J Obstet Gynaecol 1990; 97: $762-769$.

4 Cincotta RB, Brennecke SP: Family history of pre-eclampsia as a predictor for pre-eclampsia in primigravidas. Int $J$ Gynaecol Obstet 1998; 60: $23-27$.

5 Sutherland A, Cooper DW, Howie PW, Liston WA, MacGillivray I: The incidence of severe pre-eclampsia amongst mothers and mothers-in-law of pre-eclamptics and controls. $\mathrm{Br} \mathrm{J}$ Obstet Gynaecol 1981; 88: $785-791$.

6 Cooper DW, Hill JA, Chesley LC, Bryans CI: Genetic control of susceptibility to eclampsia and miscarriage. Br J Obstet Gynaecol 1988; 95: 644-653.

7 Lie RT, Rasmussen S, Brunborg H, Gjessing HK, Lie-Nielsen E, Irgens LM: Fetal and maternal contributions to risk of preeclampsia: population based study. BMJ 1998; 316: $1343-1347$.

8 Liston WA, Kilpatrick DC: Is genetic susceptibility to preeclampsia conferred by homozygosity for the same single recessive gene in mother and fetus? Br J Obstet Gynaecol 1991; 98: $1079-1086$.

9 Arngrimsson R, Bjornsson H, Geirsson RT: Analysis of different inheritance patterns in preeclampsia/eclampsia syndrome. Hypertension in Pregnancy 1995; 14: $27-38$.

10 Ward K, Hata A, Jeunemaitre X et al: A molecular variant of angiotensinogen associated with preeclampsia. Nat Genet 1993; 4: $59-61$.

11 Guo G, Wilton AN, Fu Y, Qiu H, Brennecke SP, Cooper DW: Angiotensinogen gene variation in a population case-control study of preeclampsia/eclampsia in Australians and Chinese. Electrophoresis 1997; 18: 1646-1649.

12 Arngrimsson R, Hayward C, Nadaud S et al: Evidence for a familial pregnancy-induced hypertension locus in the eNOSgene region. Am J Hum Genet 1997; 61: 354-362.

13 Lewis I, Lachmeijer G, Downing S et al: Failure to detect linkage of preeclampsia to the region of the NOS3 locus on chromosome 7q. Am J Hum Genet 1999; 64: 310-313.

14 Chen G, R Wilson, Wang SH, Zheng HZ, Walker JJ, McKillop JH: Tumour necrosis factor-alpha (TNF-alpha) gene polymorphism and expression in pre-eclampsia. Clin Exp Immunol 1996; 104: $154-159$.

15 Dizon-Townson DS, Major H, Ward K: A promoter mutation in the tumor necrosis factor alpha gene is not associated with preeclampsia. J Reprod Immunol 1998; 38: 55-61.

16 Kupferminc MJ, Eldor A, Steinman N et al: Increased frequency of genetic thrombophilia in women with complications of pregnancy. N Engl J Med 1999; 340: 9-13.

17 Sohda S, Arinami T, Hamada H, Yamada N, Hamaguchi H, Kubo T: Methylenetetrahydrofolate reductase polymorphism and preeclampsia. J Med Genet 1997; 34: 525-526.

18 Grandone E, Margaglione M, Colaizzo D et al: Factor V Leiden, $\mathrm{C}>\mathrm{T}$ MTHFR polymorphism and genetic susceptibility to preeclampsia. Thromb Haemostas 1997; 77: 1052-1054.

19 Lachmeijer AM, Arngrimsson R, Bastiaans EJ et al: Mutations in the gene for methylenetetrahydrofolate reductase, homocysteine levels, and vitamin status in women with a history of preeclampsia. Am J Obstet Gynecol 2001; 184: 394-402.

20 Hayward C, Livingstone J, Holloway S, Liston WA, Brock DJ: An exclusion map for pre-eclampsia: assuming autosomal recessive inheritance. Am J Hum Genet 1992; 50: 749 - 757. 
21 Harrison GA, Humphrey KE, Jones $\mathrm{N}$ et al: A genomewide linkage study of preeclampsia/eclampsia reveals evidence for a candidate region on 4q. Am J Hum Genet 1997; 60: 1158-1167.

22 Arngrimsson R, Sigurdardóttir S, Frigge ML et al: A genome-wide scan reveals a maternal susceptibility locus for pre-eclampsia on chromosome 2p13. Hum Mol Genet 1999; 8: 1799-1805.

23 Lander E, Kruglyak L: Genetic dissection of complex traits: guidelines for interpreting and reporting linkage results. Nat Genet 1995; 11: $241-247$.

24 Moses EK, Lade JA, Guo G et al: A genome scan in families from Australia and New Zealand confirms the presence of a maternal susceptibility locus for pre-eclampsia, on chromosome 2. Am J Hum Genet 2000; 67: 1581-1585.

25 Broman KW, Murray JC, Sheffield VC, White RL, Weber JL: Comprehensive human genetic maps: individual and sexspecific variation in recombination. Am J Hum Genet 1998; 63: $861-869$.

26 Ott J: in Ott J (ed): Analysis of Human Genetic linkage. The Johns Hopkins University Press, Baltimore, 1999; pp 272-296.

27 Kong A, Cox NJ: Allele-sharing models: LOD scores and accurate linkage tests. Am J Hum Genet 1997; 61: 1179-1188.

28 Kruglyak L, Daly MJ, Reeve-Daly MP, Lander ES: Parametric and nonparametric linkage analysis: a unified multipoint approach. Am J Hum Genet 1996; 58: 1347 - 1363.

29 Gudbjartsson DF, Jonasson K, Frigge ML, Kong A: Allegro, a new computer program for multipoint linkage analysis. Nat Genet 2000; 25: $12-13$.

30 Whittemore AS, Halpern J: A class of tests for linkage using affected pedigree members. Biometrics 1994; 50: 118-127.

31 Brown MA, Hague WM, Higgins J et al: The detection, investigation and management of hypertension in pregnancy: full consensus statement. Aust N Z J Obstet Gynaecol 2000; 40: $139-155$.
32 Redman CW: Current topic: pre-eclampsia and the placenta. Placenta 1991; 12: $301-308$.

33 Boyd PA, Lindenbaum RH, Redman CW: Pre-eclampsia and trisomy 13: a possible association. Lancet 1987; 2 : $425-427$.

34 Newman RB, Eddy GL: Association of eclampsia and hydatidiform mole: case report and review of the literature. Obstet Gynecol Surv 1988; 43: $185-190$.

35 Treloar SA, Cooper DW, Brennecke SP, Grehan MM, Martin NG: An Australian twin study of the genetic basis of preeclampsia and eclampsia. Am J Obstet Gynecol 2001; 184: 374-381.

36 Salonen RH, Lichtenstein P, Lipworth L, Cnattingius S: Genetic effects on the liability of developing pre-eclampsia and gestational hypertension. Am J Med Genet 2000; 91: 256-260.

37 Kilpatrick DC: Cohabitation and pregnancy-induced hypertension. Lancet 1994; 344: 1634; discussion 163-165.

38 Robillard PY, Dekker GA, Hulsey TC: Primipaternities in families: is the incidence of pregnancy-induced hypertensive disorders in multigravidas an anthropological marker of reproduction? Aust N Z J Obstet Gynaecol 1998; 38: 284-287.

39 Tubbergen P, Lachmeijer AM, Althuisius SM, Vlak ME, van GH Dekker GA: Change in paternity: a risk factor for preeclampsia in multiparous women? J Reprod Immunol 1999; 45: 81-88.

40 Barker DJ: Maternal nutrition, fetal nutrition, and disease in later life. Nutrition 1997; 13: 807-813.

41 Innes KE, Marshall JA, Byers TE, Calonge N: A woman's own birth weight and gestational age predict her later risk of developing preeclampsia, a precursor of chronic disease. Epidemiology 1999; 10: 153-160. 